\title{
Building Student Commitment to Agricultural Safety: A Guide for Agriculture Education Classes ${ }^{1}$
}

\section{Rob Brown, Carol J. Lehtola and Charles M. Brown ${ }^{2}$}

Safety is a primary concern in any agricultural operation. Agriculture remains one of the most dangerous occupations in the United States, mainly because agriculture requires close work with machines and livestock.

Safety experts are specially concerned when youth and young adults are involved in agricultural operations. Such a situation must occur, however, in agricultural classes in middle and high schools across Florida. A good way to prepare youth to have the safest experience in such courses is to start with a commitment to safety.

In this publication, we outline a safety packet that youth in Pasco County agriculture courses are required to complete before taking classes. This packet must be read and signed by both the student and his/her parents so that everyone is aware of what they will be working with and equally aware of the safety attitude that is needed. This packet can be helpful for other schools to use as a guide for developing a safety commitment packet. This model was approved by the Pasco County School Board as well as their legal counsel.
First, an outline of the safety commitment is presented and then the full content of the Pasco County packet. A packet is available for download at the Florida AgSafe Web site<www.flagsafe.ufl.edu>.

\section{Outline of the Safety Packet}

The Pasco safety packet includes:

I. Opening statement to parents about helping students understand the importance of safety and the contents of the safety packet.

II. Rules of the course, including: dress requirements, use of safety equipment, and student conduct.

III. A complete list of equipment and materials that students are likely to encounter, including: laboratory equipment, hand tools, powered farm equipment, livestock equipment, and power tools.

IV. Student information

V. Safety statement acknowledgment

1. This document is ABE353, one of a series of the Agricultural and Biological Engineering Department, Florida Cooperative Extension Service, Institute of Food and Sciences, University of Florida. First published July 2004. Please visit the EDIS Web site at http://edis.ifas.ufl.edu.

2. Rob Brown, vocational ag teacher, Pasco County, Florida; Carol J. Lehtola, associate professor, and Charles M. Brown, coordinator for information/publication services, Agricultural and Biological Engineering Department, University of Florida, Gainesville, Florida 32611.

The Institute of Food and Agricultural Sciences (IFAS) is an Equal Employment Opportunity - Affirmative Action Employer authorized to provide research, educational information and other services only to individuals and institutions that function without regard to race, creed, color, religion, age, disability, sex, sexual orientation, marital status, national origin, political opinions or affiliations. For information on obtaining other extension publications, contact your county Cooperative Extension Service office. Florida Cooperative Extension Service / Institute of Food and Agricultural Sciences / University of Florida / Larry R. Arrington, Interim Dean 


\section{Contents of the Pasco County Safety Packet}

\section{Opening Statement to Parents about Helping Students Understand the Importance of Safety}

\author{
District School Board of Pasco County
}

Agricultural Programs Safety Advisory Statement

[Student name] is enrolled in an agricultural class at [school name]. Agriculture classes, with their numerous career choices, offer a student exciting opportunities to learn new skills on a daily basis. As a member of the class, your student will be expected to take part in activities as directed by the Florida Department of Education to meet student performance standards outlined in the curriculum frameworks. Many of these activities involve the use of tools and equipment that are deemed appropriate and can be expected to be used in that career field. If safety rules are ignored by the student, misuse could lead to injury or death. It is the intent of the agriculture instructor to provide you, the student's parent or guardian, with an outline of the safety rules and requirements that your student will be expected to follow. Your student will receive comprehensive instruction in the safe use of all tools and equipment. Attached is a list of those tools, equipment and skills that could be a part of the student's class instruction.

\section{Learning Agricultural Safety!}

Proper dress and attitude are the key ingredients for a safe experience in agriculture class. If a student is improperly attired, the instructor will direct the student to stay out of the shop or designated work area. The student's participation grade for that day will be a 0. Make-up work will not be provided. Anyone needing special consideration will be provided with the required assistance necessary to take part in all class activities. Parents, please take the time necessary to discuss with your student the importance of these rules.

\section{Rules of the Course}

\section{The student must always work under the direct supervision of the instructor!}

2. The student must listen very carefully to the instructor's directions. If for any reason the student is uncertain what is expected, he/she should ask questions. The student should never begin a task unless he/she is certain what is expected.

3. All school board rules apply to the agricultural laboratory and will be strictly enforced.

4. Students may not wear loose-fitting or baggy clothing in the work area.

5. Skin-piercings, necklaces, bracelets, earrings, or any other jewelry may not be worn in the work area. There is a very real danger of infection or the jewelry becoming entangled in machinery leading to injury or death.

6. Long hair can become entangled in moving equipment and scalping or other injuries could occur. All long hair must be contained by a cap, hair net, clasps, scrunches, or other suitable devices.

7. As the work area in the agriculture lab may be wet, bare earth, concrete, loose soil, or even littered with animal manure, appropriate footwear is necessary. Open-toed shoes, flip-flops, sandals, and loose-fitting or poorly fitting shoes will not be allowed. In some cases, the student may wish to purchase, at his/her own expense, rubberized footwear that can be kept in a secure location at the agriculture lab facility. Safety-toe boots would be an asset, but not a requirement.

8. As required for a particular assignment, the instructor will issue hard hats, safety goggles, ear protectors, dust masks, latex gloves, leg chaps, face shields, work gloves, and protective vests. The student must wear this equipment at all times as directed by the instructor. This equipment must be returned to the instructor at the end of the class period. Any broken equipment must be reported immediately to the instructor. 
9. The student must use all safety devices on the machinery and equipment. This includes, but is not limited to, seatbelts on ROPS-equipped tractors, SMV emblems, back-up alarms, or flashing lights. Any missing or damaged safety devices must be reported to the instructor immediately. The equipment will be immediately disabled, secured, and red-tagged until repairs are completed to the instructor's satisfaction.

10. No horseplay, roughhousing, surprises, or throwing objects of any kind will be tolerated. These can cause dangerous distractions in the work area and lead to injury or death. Cell phones, CD players, walkie-talkie radios, or any other device that distracts students from the instructor's directions are prohibited from use during class time. Exception: the use by the instructor of a communication device to a student's headset for the purpose of giving operating directions to a student during tractor driving operations.

11. Pregnancies need to be discussed with the instructor. Confidentiality will be respected. The health and safety of the unborn child and expectant mother are of the utmost importance. Example 1: An unborn child can be severely affected by contact with certain chemicals that would not normally affect teens and adults. Example 2: Animals are unpredictable. An expectant mother and child can be severely injured by being kicked, dragged, knocked, or head-butted by an agriculture lab animal.

12. The student must report any injury, allergic reaction, illness, sting or event to the instructor immediately. The appropriate reports and paper work will be initiated and the school nurse contacted for follow-up.

\section{Complete List of Equipment and Materials That Students Are Likely to Encounter}

\section{Agriculture Class Tools and Equipment}

Many of these tools are presented to the students for use and identification purposes only. Only students who have passed the appropriate safety exams with a score of $100 \%$ will be allowed to work with or operate the following tools and equipment. This will only be allowed under the direct supervision of the instructor. The instructor inspects all equipment before each use. Many of these tools may never be used by the student.

\section{Laboratory Equipment}

- Electric hotplate

- Microscopes

- Balance beam scales

- Knives

- Scalpels

- Dissection kit

- Shears

- Beakers

- Test tubes

- Incubator

- Sterilizer

- Probes

- Various fertilizers

- Various chemicals

\section{Hand Tools}

- Square-end, long-handled shovel

- Round-point, long-handled shovel

- Garden trowel

- Garden shears

- Loping shears

- Pitch fork

- Manure fork

- Short-handled grain-scoop shovel 
- Socket wrench

- Ratchet handle

- Power bar

- Speed handle

- Hydraulic floor jack

- Hydraulic bottle jack

- Jack stand

- Torque wrench

- Flat screwdriver

- Phillips screwdriver

- Diagonal pliers

- Slip-joint combination pliers

- Locking jaw pliers

- Open-end pliers

- Box-end pliers

- Electrician/lineman pliers

- Ball peen hammer

- Hack saw

- Cold chisel

- Cold punch

- Allen wrench

- Pipe wrench

- Portable metal pipe vise

- Pipe cutter

-3/8-, 1/2-, 3/4-inch pipe dies

- Fence-wire stretcher

- Curved-claw hammer

- Bar clamp
- Wood chisel

- "C" clamp

- Hand-screw clamp

- Round file

- Taper or three-square file

- Wood rasp

- Carpenter's or framing square

- Combination square

- Try square

- Carpenter's level or plumb bob

- Hand-held metal shears

- Chalk line

- Tape measures: 6', 16', 25', 100', 250'

- Nail set punch

- Center punch

- Prick punch

- Jack plane

- Jointer plane

- Hand cross-cut saw

- Hand rip saw

- Woodworker's vise

- Machinist's vise

- Open-end wrench

- Box-end wrench

- Adjustable wrench

- Single-bit axe

- Double-bit axe

- Single-wheel push plow 
- Single wheel push cultivator

- Two-wheel push garden seeder

- Log peavey hook

- Manual posthole digger

- Egg candling light

\section{Powered Farm Equipment}

- Skid-steer loader

- Tractor

- Two-wheel trailer

- Moldboard plow

- Disc Harrow

- Brush mower

- Finish mower

- Cultivator

- Tractor-mounted hay bale mover forks or spear

- PTO-driven rotary tiller

\section{Livestock Equipment}

- Large animal scale

- Small animal crate scale

- Large animal grooming chute

- Large animal palpation and squeeze chute

- Hog catch snare

- Livestock trailer

- Large animal grooming clipper

- Small animal grooming clipper

- Sheep shears

- Male emasculator
- De-horning scoop

- Electric dehorning cauterizing tool

- Tattoo applicator

- Ear tag applicator

- Drenching gun

- Balling gun

- Rubber-banding pliers

- Semen storage $\mathrm{N}_{2}$ tank

- Semen electro-ejaculator

- Semen storage straws

- Syringes of various sizes

- Needles of various sizes

- Steer show halter

- Steer show stick

- Steer lead rope

- Heifer show halter

- Large animal dryer blower

- Branding iron

- Branding iron heater

- Horse bridle

- Horse halter

- Horse twitch

- Horse leads

- Horse fly mask

- Feed scoop

- Hanging feed scale

- Stationary feed scale

- Wheelbarrow 
- Feed bucket

- Two-man crosscut saw

\section{Power Tools}

- Portable electric drill, 1/4-inch

- Portable electric drill, 3/8-inch

- Portable electric drill, 1/2-inch

- Portable electric saw, 7-1/4-inch

- Electric drill press, 1/2-inch

- Electric table saw

- Electric band saw

- Electric radial arm saw, 10-1/2-inch

- Portable electric saber saw

- Electric welder, $225 \mathrm{amp}$

- Electric MIG-Wire welder

- Oxygen-acetylene welding torch set

- Palm-held electric orbital sander

- Portable electric belt sander

- Portable electric grinder, 6-inch

- Mounter stand grinder, 6-inch

- Gasoline-powered string trimmer

- Gasoline-powered lawn mower

- Gasoline-powered walk-behind rotary tiller

- Gasoline-powered generator and welder

- Chipping hammer

- Concrete mixer, 1/3-yard

- One-bag mortar mixer

The following tools and equipment will be presented for identification purposes only. The student will not be allowed to operate.
- Gasoline-powered chain saw

- Bee-keeping equipment (no live bees present)

\section{Student Information}

Student Information: This information is confidential. It will be kept in a secure place and will only be released to those school personnel as deemed necessary for the health and well-being of the student.

- Student Name

- Parent or Guardian Name

- If the student is an emancipated minor, all paper work must be completed and on file with the Pasco County School Board.

- Address

- Telephone Number

- Beeper/Cell Phone

- Primary Care Physician

- Hospital of Choice

- Are there any pre-existing allergies, health problems or limitations that the instructor needs to be aware of?

- Person to whom the student may be released in the event a parent or guardian is unavailable.

- Name•

- Relationship

- Telephone Number

- Beeper/Cell Phone

\section{Safety Statement Acknowledgment}

I have read and understood the safety information provided about the agriculture class for [student's name] attending [school name].

I have discussed the rules and information provided with my student. 
- Student signature:

- Parent/Guardian signature:

- Date:

Students who return this page, completed and signed, along with all other pages initialed and dated to the instructor before the end of the day on Friday of the first week of school will receive a Test/Quiz grade of $100 \%$. 